\title{
Sustainable Public Finance: Double Neutrality Instead of Double Dividend
}

\author{
Dirk Loehr \\ Trier University of Applied Sciences, Environmental Campus Birkenfeld, Birkenfeld, Germany \\ Email: d.loehr@umwelt-campus.de
}

Received 27 November 2015; accepted 31 January 2016; published 4 February 2016

Copyright (C) 2016 by author and Scientific Research Publishing Inc. This work is licensed under the Creative Commons Attribution International License (CC BY). http://creativecommons.org/licenses/by/4.0/

c) (i) Open Access

\begin{abstract}
A common answer to the financial challenges of green transformation and the shortcomings of the current taxation system is the "double dividend approach". Environmental taxes should either feed the public purse in order to remove other distorting taxes, or directly contribute to financing green transformation. Germany adopted the former approach. However, this article argues, by using the example of Germany, that "good taxes" in terms of public finance should be neutral in terms of environmental protection and vice versa. Neutral taxation in terms of environmental impacts can be best achieved by applying the "Henry George principle". Additionally, neutral taxation in terms of public finance is best achieved if the revenues from environmental taxes are redistributed to the citizens as an ecological basic income. Thus, distortive effects of environmental charges in terms of distribution and political decision-making might be removed. However, such a financial framework could be introduced step by step, starting with a tax shift.
\end{abstract}

\section{Keywords}

Double Dividend, Double Neutrality, Tinbergen Rule, Henry George Principle, Ecological Basic Income

\section{Introduction}

Something is going wrong. Although the ecological transformation of the developed economies is in progress, the speed is obviously too slow. An important reason for that is an inefficient and ineffective system of public finance. In this article, this statement is illustrated by using the example of Germany, which is often considered a pioneer in terms of ecological transformation. However, taking a closer look, the picture is ambiguous. For in- 
stance, on the one hand Germany has made big progress in terms of expansion of renewable energies, but on the other hand the transformation of traffic into sustainable patterns is not moving forwards fast enough. The progress of electromobility is slow, and so far motorized private transport also cannot be significantly moved from the road onto the railway.

Generally, ecological transformation needs a shift away from the conventional infrastructure, in terms of traffic, in terms of energy and electricity supply (e.g. transmission lines), in terms of water supply and waste water, and generally in terms of settlement development. The Stern review, for instance, estimated the additional costs of adapting to climate change in OECD countries to be some $\$ 15$ - 150 billion each year alone $(0.05 \%$ - $0.5 \%$ of GDP) [1]. It is hard to say how many of these costs are related to public infrastructure. While delaying the necessary changes, the costs will rise year by year. However, so far the German government is not even capable of maintaining the existing infrastructure, not to mention financing a green transformation of infrastructure. In summary, the current investment backlog for streets, electricity and the broadband network is some 160 billion Euro for the next 10 years [2]. Not included in this calculation are the necessary investments for schools, for a desirable expansion of public transport, for the adaption of the water supply network etc.

The second field of attention is still the sluggish internalization of external costs of pollution. At the turn of the millennium, on April 1, 1999, the "ecological tax reform" (subsequently called "eco tax") was introduced in Germany. The rates of existing taxes (on petrol, diesel, heating oil and natural gas) were increased in several steps-the only new tax introduced was the electricity tax [3]. However, whereas in 2003 the share of environmental taxes in the public budget was some $6.5 \%$, it had decreased to just $4.9 \%$ by 2014 -and was therefore lower than that before the introduction of the eco tax [4].

The usual answer to these challenges stresses the "double dividend approach" [5] [6]. According to this concept, environmental taxes can both reduce pollution (first dividend) and reduce the overall economic costs associated with the current tax system. Thus the revenues from environmental taxes can be used either to deal with the financial challenges of green transformation or to decrease distorting taxes or contributions to public social insurance (second dividend). Whereas environmental degradation is taxed too low, high taxation-particularly on labour-results in high unemployment rates. By shifting taxes away from labour and onto the environment, more environmental protection and higher employment can be achieved at the same time. This was also the underlying reason for the German eco tax. The promise was to reduce the contributions to the statutory pension scheme and thus create incentives for new jobs.

The discussion about the double dividend hypothesis was quite heated at the turn of the millennium [7] [8]. However, in the meantime the debate has slowed down; obviously, there was broad support of the double dividend approach among economists. Recently, Jorgenson and others came up with a new econometrical simulation which stressed the importance of the double dividend hypothesis [9].

Subsequently, we argue against the double dividend hypothesis. The fundamental criticism is that independent goals (environmental protection on the one side, economic efficiency and public finance on the other side) are pursued with one single instrument; thus the "Tinbergen rule" is violated [10]. According to the Tinbergen rule, for each and every independent policy target there must be at least one policy tool. If there are fewer tools than independent targets, some policy goals will not be achieved. Thus, contrary to the double dividend hypothesis, we assert that "good taxes" in terms of public finance should be neutral in terms of environmental protection. The other way round, "good taxes" in terms of environmental protection should be neutral in terms of public finance.

By using the "Henry George principle" as an Archimedean point, we show that-in contrast to conventional taxation - the current taxation system is anything but neutral. Then we argue why the double dividend approach cannot be considered as an application of the Henry George principle. It is demonstrated that-in the case of Germany - the application of the Henry George principle would be superior to the current taxation in terms of collecting public funds and that public finance mustn't rely on revenues from environmental taxation or auctioning pollution rights as a supplementary source of finance. Instead, environmental taxes are neutral in terms of public finance if they are redistributed to the citizens as an ecological basic income or lump-sum rebate. Thus, the regressive distributional effects of environmental charges can be tackled. Since neutrality on taxation is closely related to neutrality in political decision-making, also a potential bias of the authorities in charge can be removed. Of course the proposed reforms cannot be put into place from one day to another. Economists should think about transitional solutions which are politically feasible and acceptable. 


\section{The Ecological Changeover-How to Finance?}

\subsection{The Henry George Principle as an Archimedean Point}

In order to judge the impacts of the current tax system, we need an Archimedean point. As such, we chose the Henry George principle. The rationale of the Henry George principle (or the "Golden Rule of Local Public Finance") [11] is to tap land rents in order to avoid the taxation of the mobile factors of production, which are "labour" and "capital". Land rents are differential rents which emerge due to locational advantages, to advantages in the intensity of use or to advantages in the quality of the site [12]. However, the term "land" was used by Henry George himself in a broad sense which also includes other natural resources such as oil wells, ground water reserves, atmosphere etc. [13]. In order to make a better distinction for these and other types of resources and their revenues, we want to subsequently name land rents in a strict and narrow sense "location rents". In particular, the dimension of urban location rent depends on the transportation costs, the density and the radius of an agglomeration [14].

The basic features of the Henry George principle are illustrated in a simplified form in Table 1 ("basic Henry George theorem”, subsequently: "BHGT”). National income contains private as well as public goods and services (first column of Table 1, "Composition”). In Table 1, resources such as oil wells, water reserves etc. are not included yet. Moreover, the prices of all goods and services contain remuneration for the factors of production, which are the mobile factors "labour" and "capital" as well as the immobile factor "land" (second column of Table 1, "Distribution"). However, the illustration shows that wages and interest are costs-from a macroeconomic point of view. They have to be currently reproduced, with the corresponding input of resources. Location rents, by contrast, are not costs but a residual. They remain after the costs of labour and capital are paid out of the earned income. In the sense of the old Physiocracy, location rents might be interpreted as "social surplus" (third column of Table 1, "Features") [15].

The BHGT has been developed in different variations [11] [16] [17]. An important version considers the municipalities as competing developers which are trying to maximize the social surplus. By analogy to the optimal operational size of a company, each of them tries to find the optimal number of inhabitants in order to optimize the provision of the public good. Like in a producer cooperative, the inhabitants might be considered at the same time as owners of the company and the consumers of its output. The BHGT proves to be quite robust regarding changes of the assumptions of the original models [18].

Table 1 illustrates that, under certain conditions, the fixed costs of public services might be covered by the location rents [11]. Note that the marginal costs of public goods basically require covering by user fees [19]. However, the BHGT might be also interpreted the other way round: at least to a high degree, location rents are not created by the efforts of the land owners, but directly or indirectly (e.g. agglomeration of skilled workforce) by the supply of public goods and services.

Conventional taxation disconnects this relationship between the fixed costs of public goods and services and the location rents provided by the BHGT. We call "conventional taxation" the taxation of the mobile factors of production, including contributions to public social insurance, as well as the taxation of consumption. Conventional taxation socializes income and values which have been created by private actors. This is the precondition for privatizing income and values which have been created by the public - the location rent. In the same way as the decoupling of benefits and costs (external effects) causes market failure in the private sector, the decoupling of government revenues and expenditure is an important reason for state failure [20] [21]. For instance, due to the rule of non-assignment, tax revenues are basically not "earmarked"; instead, they are spent by the administration for all possible purposes. In the case of the German eco tax, the rule of non-assignment meant that the promise of using the revenues in order to lower the social insurance contributions had in fact been broken. In-

Table 1. Basic Henry George theorem (simplified version, own table).

\begin{tabular}{ccccc}
\hline & & National Income \\
\hline Composition & $\Leftrightarrow$ & Distribution & Features \\
Private goods and services & $\Leftrightarrow$ & Interest (capital) & Costs \\
Public goods and services (fixed costs) & $\Leftrightarrow$ & Location rents & $\Leftrightarrow \quad$ Social surplus (residual) \\
\hline
\end{tabular}


stead, the federal subsidies to the statutory pension insurance increased from 2000 to 2005 (end of the era of Chancellor Schröder) by almost the same amount as the additional revenues from the eco tax-from ca. 9 to more than 17 billion Euro [22]. Thus, the eco tax supported an important voter group for the strongest ruling party instead of contributing to lowering the distortive effects of conventional taxation in Germany.

Basically, conventional taxation decreases social welfare. In this article we reject the usual method of measuring social welfare as the added-up producer and consumer rents. Most economists agree that in particular the measurement of the change in the consumer rent is a problem if it is derived by using an uncompensated Marshallian demand function. A Hicksian demand function is not really an alternative, since the individual utility functions of the actors have to be known (then, the method of equivalent and compensating variation could be applied). However, these problems can be circumvented under the abovementioned assumption that the aggregate location rent mirrors the social surplus [15]. Although the location rent is included in the production prices, it is not cost but a residual. Any conventional taxation either decreases available income (e.g. value added tax) or increases the costs of the mobile factors of production (e.g. income tax). As a consequence, the location rent and location value gets depressed, and the current "kinetic location rent" is lower than the "potential location rent" [23]. Or, as Mason Gaffney stresses, "all tax comes out of rent" [24]. Conversely, the goal of efficiency and welfare maximization is in line with the target of avoiding additional unemployment due to taxation. Germany is a striking example for tax-induced inefficiencies. Germany is located in the centre of Europe and thus expected to have high location rents and location values. However, the opposite is the case. Instead, low-tax neighbouring countries such as Luxembourg and Switzerland have high location rents and high location values. In contrast to widespread opinion, the low land rents and land values in Germany don't indicate a success story. Instead, it suggests that the German economy is running far beneath its potential: Germany has a dual-income tax system. This means that income from capital is taxed at lower rates than income from labour as the less mobile factor of production. In addition, the costs of labour are also increased by social security contributions. According to the OECD, the tax wedge between total labour costs to the employer and the corresponding net takehome pay for average single workers without children in Germany was the third-highest of all OECD countries in 2015 [25]. Whereas Germany is a high-tax country for the average workforce, the situation for high-income earners is quite comfortable [26].

Theoretically, if the conventional taxation were to be removed, the land rents and the land values would rise correspondingly. In accordance with the BHGT, a tax on the highest and best use of locations (location value tax, "LVT") would be able to skim off the location rent. This holds true at least in the case of proper land use planning, which makes the supply function of land inelastic. Moreover, land as an inelastic factor of production can be taxed without depressing the social surplus. The depression of location rents is reversed by being simply deviated from private into public purses. By contrast, if the inflow of LVT allows a reduction in conventional taxes, economic activities might be stimulated. Thus, the social surplus increases due to the removal of the tax burden. However, the recipients of the social surplus change.

\subsection{Double Dividend Approach as "Hidden Henry George Principle"?}

Some authors assert that "the correspondence of the double dividend theory with existing resource rent theory is direct” [27]. According to this opinion, the taxation of location values skims off location rents, whereas e.g. the taxation of exhaustible resources takes resource rents. Similar rents may emerge when environmental goods, landfills or sinks have been made scarce, e.g. due to measures of police and control, pollution permits or environmental taxation. In the double dividend approach as well as within the Henry George-principle, rents can be used in order to achieve a welfare gain by avoiding or removing distorting taxes [28]. Thus, the German double dividend approach was interpreted as an application of the abovementioned Henry George-principle. However, we want to contest this argument.

The first counterargument is a systematic one. Indeed, many authors also take "rents" from the exploitation of natural resources or for instance the "atmospheric rent" due to pollution permits into consideration [29] [30]. This also includes congestion charges, which might be interpreted as Pigou "taxes" [31]. However, we argue that revenues from the exploitation of natural resources, economic instruments of environmental protection (such as fees from pollution permits or revenues from environmental taxes) or congestion fees are not "rents" in a macro-economic sense. Rents should be interpreted as a social surplus, which is an excess of national income over the costs that are ultimately necessary to reproduce the mobile factors of production. These costs also com- 
prise the degradation of the environment (increase in entropy) or congestion costs. Hence if the revenues paid for environmental goods compensate the harm, there is no social surplus. In contrast, the location rents per se are not connected with any costs of environmental degradation. It emerges even due to savings of transportation costs.

Second, the intention of environmental charges (as well as pollution permits) is to trigger a behavioural change amongst economic actors. Environmental taxes cause a negative excess burden, which describes the welfare benefits induced by a behavioural change due to environmental taxation [32]. Thus, in contrast to the LVT within the BHGT-scheme as described above, environmental taxes are not neutral in terms of allocation.

Third, the neutrality of political decision-making is closely connected to the neutrality of public finance. Within the abovementioned BHGT, which only relates to location rents, no other target is violated if the local government pursues its target to maximize public revenues. By contrast, the double dividend approach runs into a regime of disincentives, which is caused by a conflict of the financial and incentive function of environmental taxation:

- If the environmental goal has priority, the achievement of these goals may endanger the financial revenues. Within the double dividend approach, there is no guarantee for sustainable and adequate endowment of the public purse.

- If, in contrast, the financial target is prioritized, there is an incentive not to remove environmental nuisances. For instance, within a standard price approach [33], authorities may try to optimize financial revenues. However, this is not necessarily in line with optimizing the environmental target. Possibly, other more effective instruments of environmental protection will also not be used and nuisances will not be removed. For instance, smoking in public and littering with cigarettes might be punished, harmful land use can be avoided by changing land use plans, or infrastructure bottlenecks might be removed by public investments.

An absurd proposal in this regard was supported by the German Federal Environmental Agency. It pushed an ecological reform of the property tax which was to work as an environmental tax. The taxation was to be higher the more harmful the land use was [34]. However, this gives an incentive for poor municipalities to increase the planning of harmful land use in order to get higher revenues. If the public revenues depend on the outcome of the municipal plans and the municipality depends on the revenues, it cannot weigh and balance the different interests of the citizens and other stakeholders as a neutral trustee of common wealth. Instead, it may tolerate or even stimulate harmful behaviour in order to tax it.

As a consequence of the abovementioned arguments, taxes and fees with a negative excess burden or instruments with similar impacts basically shouldn’t feed the public purse. "Good environmental taxes” should be neutral in terms of public finance. Instead, the state should basically be financed by using neutral taxes without any incentive function and excess burden.

\subsection{Enough Funds by Means of Neutral Taxation?-A Simple Model}

As argued above, the public purse should be fed in as far as possible by neutral taxes. With the exception of a poll tax, which is not acceptable in terms of distribution, only a tax on the location value is neutral in terms of allocation (environment). Since, in the case of complementary strict land use planning, the supply of locations is completely inelastic, there is no excess burden. All other taxes, including value added tax, cause an excess burden. In 2013, the taxes and social contributions added up to some 1070 billion Euro. Own calculations show that at present the location rents in Germany amount to less than half of that figure. Thus, the question may arise whether enough funds can be raised even by a hypothetical confiscatory LVT.

In the subsequent section we illustrate why this is the case. The key for understanding is that the conventional taxation depresses the current location rent. Any tax shift towards a LVT removes this pressure. In order to calculate the financial capacity of a LVT, we use a simple model inspired by the theories of Physiocracy, of David Ricardo and Johann Heinrich von Thünen as well as by the New Urban Economics [35]. The starting point is the distinction between centre and periphery which is made in spatial economics. This distinction is ubiquitous; according to the principle of self-similarity it might be applied in global, continental, national, regional and local terms. This model shall be linked with the BHGT in order to compare a target state with the actual state.

In contrast to the simple forms of the BHGT, within the subsequent model the inhabitants consume and produce not only one but several goods and services with different values (private goods). In the centre, the values of the goods and services produced and consumed are higher than in the periphery. Here, the interaction between 
skilled labour force, low distances etc. also allows economies of scale. However, not only producers but also consumers show a higher willingness to pay for sites close to the centre, since the endowment with amenities and consumption opportunities is better. In general, the price for land use results from the interplay of marginal benefits and marginal costs which are related to the use of the different sites.

The aggregate willingness to pay for land use reveals the marginal benefits $\partial B / \partial x$ of the different locations. It depends on the net income which can be earned from the production of various goods and services on different sites:

$$
\partial B / \partial x=m \mathrm{e}^{b(c) \cdot x}-d-s-c-w\left(x^{*}\right)-r
$$

where $x$ is the number of the sites, which have in the simplest form of the model the same size. In our empirical application of the model, we use $x$ as the index number of the German states. In column 10 of Table 2, the numbers $\{0\}$ to $\{15\}$ indicate a ranking of the 16 German states according to their GDP/worker. Hamburg, for instance, has the highest GDP/worker and is marked with $\{0\}$, Thüringen has the lowest GDP/worker and is marked with $\{15\}$. The parameter $m$ is the maximum GDP per worker which can be earned in the centre (here: Hamburg), and $b$ is the gradient of the GDP/worker (with $b<0$ ). By deducting the depreciations (variable $d$ ) and the difference of indirect taxes and subsidies per worker (variable $s$ ) from the GDP per worker, we get the income per worker. Moreover, marginal transportation costs $c$ have to be considered. They have to be understood in a broad sense. Rising transportation costs mean a reduction in disposable income of the owners of the mobile factors of production and make households and companies move towards the centre; thus the population density in the centre is rising. The only households and companies that are not affected are those that are productive enough to bear the higher transportation costs or that don't interact with the centre. In consequence, the gradient $b$ flattens due to higher transportation costs. Hence the gradient $b$ is modelled as a function of the transportation costs $c$. Finally, the residual after paying the costs for labour $w\left(x^{*}\right)$ and capital $r$ per worker-including taxation and social insurance contributions-is the willingness to pay for land use. For the purpose of simplification, we don't explicitly consider risk premiums and employers' salaries. Moreover, the salary for simple, unqualified labour $w\left(x^{*}\right)$ is determined at the marginal land $x^{*}$-and vice versa. In the simplest version of the model, the la-

Table 2. Determination of marginal land in Germany (2004-2013) [37]-[41].

\begin{tabular}{|c|c|c|c|c|c|c|c|c|c|c|c|}
\hline $\begin{array}{l}(1) \\
\text { Year }\end{array}$ & $\begin{array}{l}(2) \\
m^{(A)}\end{array}$ & $\begin{array}{c}(3) \\
-b(c)\end{array}$ & $\begin{array}{c}(4) \\
d^{(A),(C)}\end{array}$ & $\begin{array}{c}(5) \\
s^{(A),(C)}\end{array}$ & $\begin{array}{c}(6) \\
w\left(x^{*}\right)^{(\mathrm{A}),(\mathrm{C})}\end{array}$ & $\begin{array}{c}(7) \\
r^{(A),(C)}\end{array}$ & $c^{(\mathrm{A}),(\mathrm{C})}$ & $p^{(\mathrm{A}),(\mathrm{C})}$ & $\begin{array}{l}(10) \\
x^{*(C)}\end{array}$ & $\begin{array}{l}\text { (11) Price } \\
\text { of marginal } \\
\text { land }^{(D),(E)}\end{array}$ & $\begin{array}{l}\text { (12) For } \\
\text { inform. } \\
\text { only: } \\
\text { workforce }\end{array}$ \\
\hline 2004 & 77,845 & 0.035 & 9357 & 5150 & 32,673 & 11,963 & 2909 & 1360 & 6 & 66 & 35,079 \\
\hline 2005 & 79,587 & 0.035 & 9621 & 5006 & 32,765 & 11,037 & 3135 & 1196 & $7^{\mathrm{F}}$ & 75 & 34,916 \\
\hline 2006 & 82,034 & 0.035 & 9755 & 4617 & 33,124 & 13,857 & 3282 & 1452 & 6 & 67 & 35,152 \\
\hline $2007^{\mathrm{B}}$ & 83,807 & 0.034 & 10,030 & 5368 & 33,443 & 16,942 & 3360 & 1673 & 5 & 98 & 35,798 \\
\hline $2008^{\mathrm{B}}$ & 84,052 & 0.034 & 10,100 & 5940 & 34,155 & 16,940 & 3444 & 1651 & $4^{\mathrm{F}}$ & 132 & 36,353 \\
\hline $2009^{\mathrm{B}}$ & 79,126 & 0.031 & 10,055 & 5356 & 34,243 & 12,695 & 3142 & 1296 & 5 & 106 & 36,407 \\
\hline 2010 & 82,417 & 0.031 & 10,407 & 5272 & 35,141 & 10,241 & 3469 & 1033 & $7^{\mathrm{F}}$ & 83 & 36,533 \\
\hline 2011 & 84,035 & 0.030 & 10,563 & 5586 & 36,185 & 10,691 & 3756 & 1046 & $7^{\mathrm{F}}$ & 84 & 37,024 \\
\hline 2012 & 84,376 & 0.029 & 10,726 & 5602 & 37,118 & 6014 & 3927 & 580 & 10 & 54 & 37,489 \\
\hline 2013 & 87,523 & 0.029 & 10,811 & 5549 & 37,827 & 5738 & 3767 & 572 & 10 & 67 & 37,824 \\
\hline
\end{tabular}

Legend: (A): Data related to the number of the workforce. (B): Special situation in 2009 due to the financial crises. (C): Average values for Germany as a whole. (D): The land price data don't represent a price index. (E): Refers only to residential buildings (simplification). (F): Values of city states have been skipped. Ranking according to the GDP/worker (2013): $\{0\}$ Hamburg; $\{1\}$ : Hessen; $\{2\}$ : Bavaria; $\{3\}$ : Baden-Württemberg; $\{4\}$ : Bremen; $\{5\}$ : North Rhine-Westphalia; $\{6\}$ : Rhineland-Palatinate; $\{7\}$ : Berlin; $\{8\}$ : Lower Saxony; $\{9\}$ : Schleswig-Holstein; $\{10\}$ : Saarland; $\{11\}$ : Brandenburg; $\{12\}$ : Saxony-Anhalt; $\{13\}$ : Mecklenburg-Vorpommern; $\{14\}$ : Saxony; $\{15\}$ : Thüringen. The data and calculations can be made available on request. Variables used: $m=$ maximum GDP per worker which can be earned in the centre; $b(c)=$ gradient of the GDP/worker, as a function of the transportation costs $c ; d=$ depreciation per worker; $s=$ difference of indirect taxes and subsidies per worker; $w\left(x^{*}\right)$ : salary for unqualified labour, determined at the marginal land $x^{*}$ (including taxation and social insurance contributions); $r=$ capital costs per worker; $c=$ transportation costs per worker; $p=$ price for marginal land per worker; $x^{*}=$ index of marginal land (see above). 
bour and capital are assumed to be homogenous and completely mobile (which, of course, is not true in reality). Thus, due to arbitrage, the price for unqualified labour and capital in the centre and in the periphery is equal in the long term. In the application of the model, for simplification we use average values for $d, s, w\left(x^{*}\right), r$ and $c$, always related to the number in the workforce.

Regarding the marginal costs for land use $\partial S / \partial x$, we have to consider the annualized public costs for developing and providing the sites $p$. Again, $p$ is related to the number in the workforce. Land is only used as far as the marginal costs for developing can be covered.

$$
\partial S / \partial x=p
$$

Thus, land can be used up to the point where the marginal benefits for land use is equal to the marginal costs of development:

$$
\partial B / \partial x=\partial S / \partial x \rightarrow m e^{b(c) \cdot x}-d-s-c-w\left(x^{*}\right)-r=p
$$

This is the marginal land $x^{*}$ :

$$
x^{*}=\frac{\ln (m)-\ln \left(d+s+w\left(x^{*}\right)+r+c+p\right)}{-b(c)}
$$

At this intersection point, the residual or marginal location rent $(\partial R / \partial x=\partial B / \partial x-\partial S / \partial x)$ equals zero. The costs of the mobile factors labour and capital plus the transportation costs as well as the costs of land provision can just be covered; there is no further surplus. In $x^{*}$, the social surplus is optimized under the given circumstances.

Any increase of a conventional tax, e.g. on the costs of mobile factors of production, makes the marginal land $x^{*}$ be shifted to the centre. This goes hand in hand with a positive excess burden and thus causes a welfare loss. If, for instance, the governmental investment in a railway track costs some 1 million dollars and the marginal excess burden is $20 \%$, the total cost for the economy is 1.2 million dollars. Thus the marginal social surplus decreases at any $x$ as a consequence of the higher conventional tax.

Basically, the model used can easily be tested by using an Equation (4). Note that in the empirical data the effects of taxation are included. However, the data provided in Table 2 and Table 3 have some inaccuracies due

Table 3. Potential capacity of public finance (in billions of Euro) [37]-[42].

\begin{tabular}{ccccc}
\hline \multirow{2}{*}{ Year } & Difference in employment & \multicolumn{3}{c}{ Financial gap } \\
\cline { 2 - 5 } & $\begin{array}{c}\text { Absolute difference } \\
\text { (in millions of workers) }\end{array}$ & In \% & $\begin{array}{c}\text { Absolute gap } \\
\text { (in billions of Euro) }\end{array}$ & $\begin{array}{c}\text { In \% of actual } \\
\text { taxes }\end{array}$ \\
\hline 2004 & 5291 & 15.1 & 221.0 & 26.3 \\
2005 & 5790 & 16.6 & 285.1 & 33.5 \\
2006 & 5279 & 15.0 & 231.2 & 25.9 \\
2007 & 4345 & 12.1 & 161.8 & 17.3 \\
2008 & 3923 & 10.8 & 150.8 & 15.7 \\
2009 & 4558 & 12.5 & 202.3 & 21.7 \\
2010 & 5251 & 14.4 & 393.9 & 41.7 \\
2011 & 4952 & 13.4 & 389.1 & 38.7 \\
2012 & 6025 & 16.1 & 588.3 & 56.5 \\
2013 & 5928 & 15.7 & 724.4 & 69.6 \\
Average (10 years) & 5134 & 14.2 & 334.8 & 34.7 \\
\hline
\end{tabular}

The data and calculations can be made available on request. 
to a lack of reliable statistics. In Germany, official statistics mix location rents, other economic rents, employer's salaries, interest rates and all sorts of risk premium in one residual statistical category ("Einkommen aus Unternehmertätigkeit und Vermögen"). In particular, inaccuracies emerge within the assessment of the capital income share. In Table 2, it has been computed by applying an average interest rate on the value of the total assets of the German economy. As a consequence, for instance the interest on consumer loans is not included.

The model only holds true if $x^{*}$ describes the marginal land. Newly developed marginal land is expected to cover only the costs of development, not more. At the beginning of the new millennium, the costs of development for marginal land were some 50 - 70 Euro/sqm, normal capital market conditions provided [36]. Table 2 shows the results for the level of the German states from 2004-2013: indeed, the columns 10 and 11 in Table 2 indicate that from 2004 to 2006 the price of marginal land moved around this mark. For instance, in 2004 the margin $x^{*}$ was $\{6\}$ (column 10). This is the scoring of Rhineland-Palatinate. There, the price for newly developed land was some 66 Euro/sqm per average. The years 2007, 2008 and 2009 were obviously statistical outliers. Due to the economic crisis, the marginal land moved towards the centre. From 2010 on, the marginal land moved to the periphery again. However, due to general inflation, the costs of development had increased meanwhile. Nonetheless, the low interest rates in 2012 and 2013 meant that the costs of land development also decreased significantly (see column 9 and 11). Note that the prices of marginal land are not derived from a land price index. Although some data (such as $c$ and $p$ ) can be assessed only roughly, the result confirms the abovementioned model.

Economizing is also possible beyond the marginal land, but only due to a supportive financial equalization scheme. This is why particularly in some states of Eastern Germany, land was often developed out of an emergency situation in order to attract inhabitants although the land prices didn't cover the development costs. Thus, Table 2 also gives an indication that particularly some of the Eastern German states can be considered as marginal locations.

Now, against the background of the BHGT as a reference model, we can roughly assess the financial gap G caused by the actual distortive, not neutral conventional taxation. According to the BHGT, the maximum financial potential of the state is the complete levy of the potential location rent. Finally, any tax burden falls either on labour, capital or land. At present, mainly wages and capital income are taxed. In contrast, in Germany land is almost not taxed. Property taxes amount only to some $2 \%$ of the total tax revenues, and only a fraction of these revenues relate to land. The lion's share is accounted for by the buildings (which is capital). Only personal or corporate income tax and business tax capture a small share of the location rents. However, taxes are basically levied on the mobile factors of production. Within the BHGT reference scenario, we assume net and gross wages to be the same. We also assume that the net wage per worker of the reference scenario corresponds with the empirical data - this means the additional distribution space due to a tax shift is not used for wage increases. Moreover, due to the absence of conventional taxes, also capital costs are reduced. On this basis we assess the marginal location rent under the condition of a tax release of labour and capital [24] by modifying Equation (3) into (5). The marginal location rent in the absence of conventional taxation is

$$
\partial R / \partial x=m \mathrm{e}^{b(c) \cdot x}-d^{-}-c-w^{-}(x)-r^{-}-p
$$

In (5), the tax free wages $w^{-}$are calculated as

$$
w^{-}(x)=\frac{w\left(x^{*}\right)}{1+t_{w}}
$$

with $t_{w}$ as the actual rate of taxes and social contributions on workforce. During 2004 and 2013, $t_{w}$ was some 84\% per average. For reasons of data availability, the depreciation of tax free equipment $d^{-}$and tax free capital costs $r^{-}$are computed in a different way:

$$
d^{-}+r^{-}=(d+r)^{-}=(d+r) \cdot\left(1-t_{q}\right)
$$

with $t_{q}$ as the tax rate on capital equipment and capital costs. During 2004 and 2013, the value of $t_{d}$ has been assumed with some $17 \%$.

In order to compute the potential location rent $R$, we have different possibilities. Since the anti-derivative is a non-unique inverse of the derivative in Equation (5), we don't use an indefinite integral. Instead, we take the average location rent $\bar{R}$ for the land with the average GDP/worker $\bar{x}$, instead of the marginal land. Since $\bar{x}$ is 
unknown for the BHGT scenario, it has been alternatively calibrated by using the empirical GDP data. It shall be assumed that the empirical $\bar{x}$ doesn't differ from the value in the BHGT reference model. The results have been crosschecked by using a conventional Cobb-Douglas production function for calculating the national income. Since all data are related to the number of workers, the result is the average potential location rent $\bar{R}$. In the next step, this average potential location rent has to be multiplied by the number of workers. The relationship between the marginal land $x^{*}$ and the employed workforce $n^{*}$ has been calculated by using a regression analysis. The regression equation has been applied to the relationship between the marginal land $x^{* *}$ in the BHGT scenario and the corresponding number of workers $n^{* *}$. The potential location rent $R$ is the product of $\bar{R}$ and the number of workers $n^{* *}$ in $x^{* *}$. Hence the financial gap $G$ is the difference between the potential location rent $R$ and the actual tax revenues $T$ :

$$
G=R-T=n^{* *} \cdot \bar{R}-T
$$

or

$$
G=n^{* *} \cdot\left(m \mathrm{e}^{b(c) \cdot \bar{x}}-w^{-}-d^{-}-r^{-}-c-p\right)-T
$$

In the subsequent Table 3, the potential location rents for the ten years before 2013 have been summarized as average values (in \%) compared with the values realized:

Table 3 indicates the superiority of the BHGT regime in terms of employment as well as in terms of financial revenues. Within the calculation presented, the average excess burden of the current taxation is at present some $13 \%$; this is largely in line with the results of other researchers [43]. This excess burden can be completely avoided within the BHGT regime. Moreover, also those land rents are allocated into the public purse, which are privatized at present. The financial gap is considerably higher than the structural funding deficit in Germany, which had been assessed to be some 3\% of the GDP in the year before the introduction of the debt cap in 2011 [44]. Considering the fact that $x^{* *}$ is some $\{21\}$ per average, this implies an imported workforce and an even higher structural foreign trade surplus compared with the present. Hence, particularly in 2012 and 2013, significantly higher wages would also have been possible. Alternatively, shares of the fiscal surplus could be redistributed to the citizens. Moreover, due to the lower rate of unemployment, less social transfers are also needed. This money could be used for green transformation instead. Considering the impacts on public finance, actually the low interest rates during recent years provided relief for the public purse. However, the financial potential of the low-interest phase has not nearly been exhausted within the conventional taxation.

The potential location rent can be skimmed off by a LVT on the highest and best use of the locations, but never by means of conventional taxation. The hypothetical attempt to do so would cause a shift of the marginal land $x^{*}$ to the origin $\{0\}$ - as a consequence, the whole economy would be strangulated. These limits of conventional taxation are another important reason for the increasing debts of municipalities and other public bodies. Thus, conventional taxation is more than just inefficient, it is also ineffective in terms of public finance and in terms of the ecological targets. On the one hand, the excess burden strangulates production without regarding its ecological impacts. Moreover, while making detours (excess burden), additional material flows are caused and additional resources are used. On the other hand, due to a lack of financial support, the green transformation is hampered. If, instead, conventional taxes are reduced in favour of a higher tapping of the location rent, the social surplus may even rise, due to a lower excess burden. This idea can be traced back to Physiocracy [15].

Note again that the BHGT only makes a statement about the coverage of the fixed costs of the state. The marginal costs of public services should be covered by fees. Such fees have similar impacts as the costs of the provision of private goods and services. Because higher costs for public services depress the location rents, the overall financial capacity of the state wouldn't change much by considering these fees explicitly in the model.

\section{Environmental Charges and Ecological Basic Income}

So far, we have shown that the application of the BHGT would improve the situation of the workforce as well as the potential of public finance significantly by exhausting the location rents. However, Stiglitz and others propose to generalize the Henry George principle for other sources of revenues, such as agricultural quotas, import quotas, taxi licenses, fishing licenses, liquor-selling licenses, electromagnetic spectrum licenses etc. [28] [32]. For instance, let's look at the time slots for starting and landing at coordinated airports. The airlines allowed to start and land at favourable times do better business than their competitors [45]. Hence the value of favourable 
time slots might be quite high — in some cases it might be the major share of the value of an airline company. However, according to the IATA rules, time slots are allocated basically by means of "grandfathering"-although the beneficiaries are allowed to sell the rights under certain conditions. In most cases, the airlines only pay an administration fee, which is only a fraction of the value of the time slot [46]. The beneficiaries of the privatized rents are mainly the big established airline companies. Basically, it is desirable for such time slots to be auctioned to the airline companies.

However, concerning this extension of the Henry George principle, we partially disagree. The above mentioned fields of generalization of the Henry George-principle have one thing in common: The access restrictions, which are necessary in terms of allocation, are not made by means of price control (such as environmental taxes) but by quantity control - the creation of limited and exclusive user rights. Since the allocative target is achieved directly by quantity control, most economists don't talk about a "negative excess burden” in this context. However, the purpose of the instruments as well as the allocative result might be comparable to environmental taxes. For these reasons, the revenues from auctioning the abovementioned rights can be treated basically the same as environmental taxes with their negative excess burden. There are good reasons why the revenues from both sorts of instruments shouldn't feed the public budget:

First, we showed that the state doesn't depend on the additional revenues from environmental taxes or on the revenues from auctioning access rights if the BHGT is applied. By contrast, the BHGT will generally show better results than conventional taxation. We will endorse this argument below.

Second, there is no logical link between the financial needs of the public and the revenues from environmental taxes or the auctioning of access rights. The optimal level of pollution does not necessarily correspond to the optimum for the public budget. Quite the contrary, the achievement of environmental goals may erode the revenues of environmental taxes and a sufficient endowment of the public purse may depend on the non-achievement of the environmental goals. In addition, environmentally friendly behaviour is incentivized best by using narrow tax bases in order to stimulate environmentally friendly substitutional choices. By contrast, without applying the Henry George-principle, the financial needs of the state and efficiency requirements suggest broad tax bases, as are applied for instance within value added taxation.

Third, the double dividend strategy doesn't remove conventional taxation with its positive excess burden. Instead it supplements environmental taxes with their negative excess burden. Even if the funds are used to reduce social security contributions or to stimulate ecological investments, it is anything but certain whether or not these effects overcome the depressing effects on employment. Thus, in order to be on the safe side, politicians may hesitate to raise environmental charges to the extent necessary from an environmental point of view. By contrast, looking at the efficiency and employment effects, the mere shift to neutral taxation would reduce unemployment, as Table 3 illustrates.

Fourth, the neutrality of taxation is closely connected with the neutrality of political decision-making. In the absence of the application of the BHGT, a lack of public funds may be an important reason why environmental goals are sacrificed by the public administration. For instance, choosing between the protection of an agricultural area and its development into a settlement area, the latter option is clearly the more lucrative one for a German municipality in charge. Inhabitants and commerce mean higher business taxes, property taxes and higher shares from income taxes within the financial equilibrium scheme. Thus, German municipalities, which are at the same time the local planning authorities, are often biased. The goal of the Federal Government's national sustainability strategy to reduce the daily consumption of new land to 30 hectares by 2020 [47] seems difficult to achieve under these circumstances. Basically the same might be said about the abovementioned access rights: Regarding for instance protection against aircraft noise, it might be necessary to restrict the timeslots; concerning public revenues, it might be desirable to extend them. What is good for the public purse and for the reelection of the politicians in charge is not necessarily desirable for the environment.

To sum up, it can be said that neutral taxation is a proper means to achieve the economic and financial targets. A tax on the location value is such a neutral tax. Within the BHGT, the city planners don't run into any conflict of interests: The size of the city and/or the number of inhabitants has to be planned in a way that optimizes the revenues of the public developer out of LVT. Moreover, since due to a shift to such a neutral taxation many distortions of conventional taxation could be removed, Dwyer calls such a regime "super neutral” [15]. By contrast, conventional taxation is not neutral due to its positive excess burden. Also the proposed extensions of the Henry George-principle might be distortive in terms of political decision-making. The least neutral taxes are environmental taxes, since they are supposed to cause a negative excess burden [32]. Moreover, within the double divi- 
dend approach they also may distort political decision-making.

Finally, political decision-making in democratic societies also has to take distributional impacts into account. Also in this regard the LVT is "super neutral": although it doesn't imply an active redistribution mechanism, a tax shift onto the LVT removes the abovementioned tax wedge on labour income. Moreover, despite the lowinterest phase of recent years in Germany, the share of gross wages ("Arbeitnehmerentgelte") in national income decreased from 67.9\% (2004) to 66.6\% (2013) [39]. Although German official statistics don’t provide any sound information, obviously the decline of the capital market interest rates did not benefit labour that much, but—as in other countries [48] — primarily worked in favour of the location rents and other economic rents. Since such rents probably also account for a significant share of the company profits [49], a LVT is a proper means to reduce this distributional bias.

Regarding measures of environmental protection, we mostly will find regressive effects-no matter whether police and control or economic instruments of environmental protection are used. As a result of higher environmental protection, the price of products will rise and the real income of the consumers will fall. That's the reason why environmental taxes are often unpopular and it is quite difficult to implement such instruments in the political process. Necessary actions are often not taken, since politicians are afraid to be removed from office at the next elections. A famous example is the decision of the German Green Party to call for a petrol price of 5 German marks/litre in 1998 by increasing the tax on petrol. Although this policy was supported by environmental experts [50], the following state elections turned out to be a disaster for the Green Party.

In order to strengthen the acceptance of an environmental charge, the revenues shouldn't feed the public purse, but should instead be redistributed to the citizens as an ecological basic income or a lump-sum rebate [29]. In combination with a policy shift to the BHGT, there are no political alternatives to be considered in the form of a reduction of a tax on capital or labour. An ecological basic income is a favourable way to make a charge neutral in terms of public finance and political decision-making.

Within such a regime, every citizen might be regarded as a co-owner of the ecological system in equal shares. If the economic activities of a certain actor degrade the environment, he/she has to compensate the other coowners by paying into a public fund. From this point of view, the internalization of external costs onto polluters and the compensation of the co-owners are no independent goals. This is why the redistribution of environmental charges doesn't violate the Tinbergen rule. The effects of the redistribution are as follows:

- If somebody's activities degrade the environment (increase entropy) more than the average of the citizens, he/she pays more into the public fund than he/she gets back (as basic income).

- If somebody contributes to the degradation of environment as much as the average of the citizens, he/she pays basically the same as he/she gets back. The average use of the environment is cost free this way.

- If, finally, somebody contributes less to the degradation of the environment than the average of the population, he/she gets back more than he/she paid. In the end, he/she gets compensation for tolerating the aboveaverage use of his/her fellow citizens.

Every single citizen has an incentive to get a positive payment balance, and could achieve that by environmentally friendly behaviour. Moreover, if, due to a stricter environmental policy, the prices of goods and services are rising, the basic income also increases. By this means, the substitution effect, which is caused by the change in relative prices, is partially compensated by the income effect of the redistribution. In particular, lowincome households are expected to benefit from such an ecological basic income [51]. This is why such a regime is expected to contribute to a higher acceptance of a stricter environmental policy. By doing so, according to own rough calculations, at present a lump-sum rebate of more than 1000 Euro per year could easily be possible in Germany.

Moreover, the public revenues from the auctions of time slots, taxi licenses, fishing licenses, highway tolls etc. should also be included in such an ecological basic income. Thus, the governmental decision-making on environmental issues can be geared only to the common good and not to its own budget—a conflict of goals cannot take place.

Note that within such a regime the redistributed money doesn't really get lost for the public purse. Only the way of collection changes, from direct to indirect. That is because the social surplus is a residual. In case of an ecological basic income or a lump-sum rebate, the income of the private households is not depressed but compensated. Hence also the social surplus (the location rent) does not decrease. This is why a huge share of the ecological basic income can be recollected again by charging the land values.

However, an ecological basic income shouldn't be confused with an unconditional basic income [52]. The 
ecological basic income doesn't intend to provide a subsistence minimum. Moreover, unlike the unconditional basic income, the ecological basic income doesn't want to decouple (income and labour) but to connect benefits and costs of environmental damage. Finally, the ecological basic income shall be paid out of the compensation of environmental degradation, whereas the unconditional basic income shall be paid out of taxes (preferentially value added tax).

\section{Conclusions and Outlook}

Sustainability also comprises public finance. On the one hand, public revenues should be sufficient to finance green transformation without shifting an additional fiscal burden to future generations. On the other hand, external effects should be internalized by economic instruments of environmental protection, without any misleading incentives for economic actors and policy makers. In this article, by using the example of Germany, we tried to substantiate why

- "good taxes" in terms of public finance should be neutral, considering environmental protection and allocation aspects and

- "good taxes" in terms of environmental protection should be neutral, considering the topic of public finance. The conflict of fiscal and environmental goals is the reason why environmental taxes shouldn't feed the public purse. Such independent and even opposing goals shouldn't be pursued by the same instrument. This is the basic reason why we reject the double dividend hypothesis. By the way, the §3 I of the German Tax Code ("Abgabenordnung") is also inexpedient and unreasonable in that it allows the pursuit of financial and allocative targets at the same time.

The fiscal target should be pursued by using neutral taxes without any excess burden, neither negative nor positive. In particular, they shouldn't have any impact on the achievement of the environmental goals. Within the BHGT, a municipality that optimizes its own public budget also maximizes public welfare at the same time. In this regard, the land value tax is the means of choice for the endowment of the public budget. Environmental charges, by contrast, cause a negative excess burden. In order to keep them neutral in financial terms, they should be redistributed to the citizens as an ecological basic income or a lump-sum rebate. The same holds true for charges from auctioning of time slots, taxi licenses, fishery licenses etc. The optimal cap, e.g. in terms of environmental impacts, may collide with the requirements of public finance. This is why they should also be included in the redistribution regime. Since an ecological basic income increases available income and location rents, it wouldn't get lost for the public purse. Together with the confiscation of the location rent, this policy may reduce a possible distributional bias. Thus, it strengthens the acceptance of environmental policy. Moreover, it also removes possible distortions in political decision-making.

However, the financial system proposed here has even deeper impacts: for instance, the BHGT as presented above presupposes a competitive federalism which is not distorted by a financial equalization scheme. Moreover, it is generally acknowledged that market failure can be contained by a better decoupling of benefits and costs in order to reduce external effects. However, basically the same holds true with state failure. Among others, state failure may arise if the state is unable to raise enough funds or the funds are spent in a way which doesn't increase public wealth. This may happen in particular if private values are socialized and public values are privatized at the same time. Thus, also in the field of public finance costs/expenses and benefits/revenues have to be connected. The coupling of costs/expenses and benefits/revenues in the field of public finance means a shift away from conventional taxation, defined as a compulsory levy without any individual consideration. Instead, the promising way is the principle of equivalence and reciprocity, which corresponds with the legal nature of fees. This principle was already stressed by Proudhon [20]. Basically, public goods should be delivered to the citizens at marginal costs. According to the basic Henry George theorem, the fixed costs of the underlying public infrastructure could be financed by location rents-because these rents have been created to a significant extent directly or indirectly by public infrastructure. And environmental charges should be used to compensate the fellow citizens for their loss-caused by the degradation of the environment.

Of course, in a democracy such a transformation of public finance is slow, in particular if it is influenced by vested interests. Such a change cannot be accomplished from one day to another. Concepts for a transition period are necessary. This is why second-best solutions have to be developed in order to step at least slowly in the right direction. Such second-best solutions could take the form of a gradual tax shift. Nonetheless, these secondbest solutions also need to be assessed, and for such an assessment a compass is needed. The above mentioned 
features of a sustainable system of public finance try to serve as such a compass.

\section{References}

[1] Stern, N.H. and Great Britain (2007) The Economics of Climate Change: The Stern Review. Cambridge University Press, Cambridge.

[2] IW Köln (2014) Infrastruktur zwischen Standortvorteil und Investitionsbedarf. Cologne, Germany. http://www.iwkoeln.de/wissenschaft/veranstaltungen/beitrag/pressekonferenz-infrastruktur-zwischen-standortvorteil-u nd-investitionsbedarf-145161

[3] Görres, A. (2005) Germany’s Ecotax Reform 1999-2003: Implementation, Impact, Future Development. Applied Environmental Economics Conference (envecon), London (Great Britain). http://www.foes.de/pdf/GBG-GreenEssay-2005-03-Goerres-Germanys-ecotax-reform-1999-2003.pdf

[4] Ludewig, D., Mahler, A. and Meyer, B. (2015) Zuordnung der Steuern und Abgaben auf die Faktoren Arbeit, Kapital, Umwelt, Background Paper. http://www.foes.de/pdf/2015-01-Hintergrundpapier-Steuerstruktur.pdf

[5] Pearce, D. (1991) The Role of Carbon Taxes in Adjusting to Global Warming. The Economic Journal, 101, 938-948. http://dx.doi.org/10.2307/2233865

[6] Stiglitz, J. (2000) Economics of the Public Sector. 3rd Edition, Norton, New York.

[7] Goulder, L.H. (1995) Environmental Taxation and the "Double Dividend”: A Reader's Guide. International Tax and Public Finance, 2, 157-184. http://dx.doi.org/10.1007/BF00877495

[8] Bovenberg, A.L. (1999) Green Tax Reforms and the Double Dividend: An Updated Reader's Guide. International Tax and Public Finance, 6, 421-443. http://dx.doi.org/10.1023/A:1008715920337

[9] Jorgenson, D.W., Goettle, R.J., Ho, M.S. and Wilcoxen, P.J. (2013) Double Dividend: Environmental Taxes and Fiscal Reform in the United States. MIT-Press, Cambridge, Mass, USA.

[10] Tinbergen, J. (1952) On the Theory of Economic Policy. North-Holland, Amsterdam.

[11] Arnott, R.J. and Stiglitz, J.E. (1979) Aggregate Land Rents, Expenditure on Public Goods, and Optimal City Size. Quarterly Journal of Economics, 93, 471-500. http://dx.doi.org/10.2307/1884466

[12] Ricardo, D. (1817/2004) On the Principles of Political Economy and Taxation. Liberty Fund, Inc., Allison Pointe Trail.

[13] George, H. (1920) Progress and Poverty. Doubleday, Page \& Co., Garden City. http://www.econlib.org/library/YPDBooks/George/grgPP.html

[14] Geltner, D.M., Miller, N.G., Clayton, J. and Eichholtz, P. (2007) Commercial Real Estate. Thomson Higher Education, Mason.

[15] Dwyer, T. (2014) Taxation: The Lost History. The American Journal of Economics and Sociology, Annual Supplement, 73, 664-988. http://dx.doi.org/10.1111/ajes.12082 3

[16] Atkinson, A.B. and Stiglitz, J.E. (1987) Lectures on Public Economics. McGraw-Hill Book Co., London.

[17] Fu, S. (2005) Essays on Urban Agglomeration Economies. PhD Dissertation, Boston College, Chestnut Hill.

[18] Kirn, T. (2010) Anreizwirkungen von Finanzausgleichssystemen. PhD Dissertation, University Potsdam, Peter Lang Verlag, Frankfurt.

[19] Vickrey, W. (1948) Some Objections to Marginal-Cost Pricing. The Journal of Political Economy, 56, 218-238. http://dx.doi.org/10.1086/256674

[20] Proudhon, P.-J. (1860/2012) Theorie der Steuer. Metropolis, Marburg.

[21] Löhr, D. (2013) Prinzip Rentenökonomie-Wenn Eigentum zu Diebstahl wird. Metropolis, Marburg.

[22] Bundeszentrale für politische Bildung (2014) Einnahmen und Ausgaben der gesetzlichen Rentenversicherung (RV). http://www.bpb.de/nachschlagen/zahlen-und-fakten/soziale-situation-in-deutschland/61857/einnahmen-und-ausgaben

[23] Foldvary, F. (2012) Why Rent Matters: The Hidden and Suppressed Economic Rent. Proceedings of the WEAI Conference, San Francisco, 30 June 2012. http://www.foldvary.net/works/rent-wea-12.doc

[24] Gaffney, M. (2009) The Hidden Taxable Capacity of Land: Enough and to Spare. International Journal of Social Economics, 36, 328-411. http://dx.doi.org/10.1108/03068290910947930

[25] OECD (2015) Taxing Wages 2015-Germany. http://www.oecd.org/germany/taxing-wages-germany.pdf

[26] Kaiser, T. (2014) Deutschland ist bei Abgabenlast absolute Weltspitze. Die Welt, April, 11. http://www.welt.de/wirtschaft/article126829990/Deutschland-ist-bei-Abgabenlast-absolute-Weltspitze.html

[27] Jaeger, W.K. (1999) Double Dividend Reconsidered, Working Paper. http://belfercenter.hks.harvard.edu/files/jaeger.pdf 
[28] Stiglitz, J.E. (2014) Reforming Taxation to Promote Growth and Equity. White Paper, Roosevelt Institute, 28. http://rooseveltinstitute.org/wp-content/uploads/2014/05/Stiglitz_Reforming_Taxation_White_Paper_Roosevelt_Instit ute.pdf

[29] Barnes, P. and Pomerance, R. (2000) Pie in the Sky—The Battle for Atmospheric Rent. Washington DC. http://community-wealth.org/sites/clone.community-wealth.org/files/downloads/paper-barnes-pomerance.pdf

[30] Fullerton, D. and Metcalf, G.E. (1997) Environmental Taxes and the Double-Dividend Hypothesis: Did You Really Expect Something for Nothing? NBER Working Paper No. 6199, September. http://www.nber.org/papers/w6199

[31] Policy Advisory Council of the German Federal Ministry of Economics and Energy (Wissenschaftlicher Beirat beim Bundesministerium für Wirtschaft und Energie) (2014) Engpassbasierte Nutzerfinanzierung und Infrastrukturinvestitionen in Netzsektoren. Berlin.

http://www.bmwi.de/BMWi/Redaktion/PDF/Publikationen/Studien/wissenschaftlicher-beirat-engpassbasierte-nutzerfin anzierung-und-infrastrukturinvestitionen-in-netzsektoren,property=pdf,bereich=bmwi2012,sprache=de,rwb=true.pdf

[32] Tideman, T.N. and Plassmann, F. (2015) Sources of Public Revenue that make Nations Richer. Economic Affairs, 35, 197-214. http://dx.doi.org/10.1111/ecaf.12116

[33] Baumol, W.J. and Oates, W.E. (1971) The Use of Standards and Prices for Protection of the Environment. The Swedish Journal of Economics, 73, 42-54. http://dx.doi.org/10.2307/3439132

[34] Bizer, K. and Lang, J. (2000) Ansätze für ökonomische Anreize zum sparsamen und schonenden Umgang mit Bodenflächen. UBA-Texte 21-00, Federal Environmental Agency, Berlin.

[35] Harrison, F. (2006) Ricardo’s Law-House Prices and the Great Tax Clawback Scam. Shepheard-Walwyn, London.

[36] Gutsche, J.-M. (2003) Auswirkungen neuer Wohngebiete auf die kommunalen Haushalte-Modellrechnungen und Erhebungsergebnisse am Beispiel des Großraums Hamburg. ECTL Working Paper 18.

http://www.tuhh.de/vpl/publikationen/ectl-working-paper.html

[37] German Federal Statistical Office (Statistisches Bundesamt) (2015) Preise-Kaufwerte für Bauland, Fachserie 17, Reihe 5, Wiesbaden.

https://www.destatis.de/DE/Publikationen/Thematisch/Preise/Baupreise/KaufwerteBaulandVj2170500143234.pdf?_b lob=publicationFile

[38] Statistical Offices of the German States (Statistische Ämter der Länder) (2014) Volkswirtschaftliche Gesamtrechnungen der Länder, Reihe 1, Länderergebnisse, Volume 1-5, Frankfurt.

[39] German Federal Statistical Office (Statistisches Bundesamt) (2014) Statistisches Jahrbuch (Statistic Yearbook) 2014, Wiesbaden.

[40] German Federal Statistical Office (Statistisches Bundesamt) (2014) Sektorale und gesamtwirtschaftliche Vermögensbilanzen 1999-2013, Wiesbaden.

[41] Deutsche Bundesbank (2014) Umlaufsrenditen inländischer Inhaberschuldverschreibungen/Anleihen von Unternehmen (Nicht-MFIs), BBK01.WU0022, BBK01.WU0022_FLAGS. https://www.bundesbank.de/Navigation/DE/Statistiken/Zeitreihen_Datenbanken/Makrooekonomische_Zeitreihen/its_d etails_value_node.html?tsId=BBK01.WU0022

[42] IW Köln (2015) Deutschland in Zahlen 2015, Cologne.

[43] German Council of Economic Experts (Sachverständigenrat zur Begutachtung der gesamtwirtschaftlichen Entwicklung) (2005) Die Chancen nutzen—Reformen mutig voranbringen, Jahresgutachten 2005/06. Wiesbaden.

[44] German Council of Economic Experts (Sachverständigenrat zur Begutachtung der gesamtwirtschaftlichen Entwicklung) (2010) Chancen für einen stabilen Aufschwung, Jahresgutachten 2010/11, Wiesbaden.

[45] Olbrich, M., Dallmayr, C. and Zilch, C. (2009) Zur IFRS-Bilanzierung immaterieller Vermögenswerte aufgrund von immateriellen Zuwendungen-eine Analyse am Beispiel von Start- und Landerechten. Betriebswirtschaftliche Forschung und Praxis, 61, 207-221.

[46] Zirm, M. (2011) Die Vergabe von Start- und Landerechten auf Flughäfen-Internationale, europäische und nationale Regelwerke, VDM Verlag, Saarbrücken.

[47] Federal Government of Germany (Bundesregierung) (2002) Perspektiven für Deutschland-Unsere Strategie für eine nachhaltige Entwicklung, Berlin. http://www.bundesregierung.de/Content/DE/_Anlagen/Nachhaltigkeit-wiederhergestellt/perspektiven-fuer-deutschland -langfassung.pdf?_blob=publicationFile\&v=3

[48] Rognlie, M. (2015) Deciphering the Fall and Rise in the Net Capital Share. BPEA Conference Draft, March 19-20. http://www.brookings.edu/ /media/projects/bpea/spring-2015/2015a_rognlie.pdf

[49] Löhr, D. (2013) Equity and the Hidden Factor Land: A Hypothesis. Society and Business Review, 8, 107-118. http://dx.doi.org/10.1108/SBR-01-2013-0004 
[50] N.P. (1998) Streit um Benzinpreisbeschluß hält an. Die Welt, 31 March. http://www.welt.de/print-welt/article597726/Streit-um-Benzinpreis-Beschluss-haelt-an.html

[51] Williams, R.C., Gordon, H., Burtraw, D., Carbone, J.C. and Morgenstern, R.D. (2014) The Initial Incidence of a Carbon Tax across Income Groups. Discussion Paper. http://www.rff.org/files/sharepoint/WorkImages/Download/RFF-DP-14-24.pdf

[52] Werner, G. (2007) Einkommen für alle, Kiepenheuer und Witsch, Cologne. 